\title{
"Cricket singing means rain": semiotic meaning of insects in the district of Pedra Branca, Bahia State, northeastern Brazil
}

\author{
ERALDO M. COSTA NETO \\ Departamento de Ciências Biológicas, Universidade Estadual de Feira de Santana \\ Km 03, BR 116, 44031-460 Feira de Santana, BA, Brasil \\ Manuscript received on December 16, 2004; accepted for publication on August 17, 2005; \\ presented by LuCia MENDONÇA PREVIATO
}

\begin{abstract}
This paper deals with the semiotic meanings which are given both to the appearance and/or behavior of insect species according to the ethnoentomological knowledge of the inhabitants of the village of Pedra Branca, Bahia State, Brazil. Data were collected from February to May 2001 by performing open-ended, recorded interviews with nine men and twenty-five women, whose ages ranged from 19 to 82 years old. Data were analyzed by using the union model, which involves considering all available information on the surveyed subject. Twelve kinds of insects were associated with both beneficial and harmful events, as well as with the indication of changing weather. The way local people perceive and interpret the appearance and/or behavior of certain species of insects depends on the cultural background of each inhabitant. The following semiotic meanings were recorded: fatal, funereal, auspicial, meteorological, societal, monetary, and of abundance or scarcity. The beliefs in the augural power of insects in the village of Pedra Branca are deep-rooted in the local tradition and are transmitted from generation to generation through oral culture. It is hoped that the data now available will be incorporated into a curriculum by those researchers interested in insect conservation and ethnobiology as well.
\end{abstract}

Key words: bioindicator, ethnoentomology, folk knowledge, semiotic meaning.

\section{INTRODUCTION}

People from different cultural backgrounds worldwide look at the elements of nature as significant signals to predict a great range of situations. The behavior of animals and the appearance or characteristics of plants has guided the first observations and deductions human beings have had about the weather and other day-to-day events (Clausse 1973). For example, in Western Kenya individuals use toads, birds and white ants as indicators of the arrival of rains, while in the northeast of Tanzania the changes in the behavioral patterns of birds, in-

E-mail: eraldont@hotmail.com sects and mammals are important signs (Prendergast et al. 1999). In Japan, the names of invertebrates are used metaphorically as synonymous of the seasons. Different names of arthropods, such as flea, housefly, mosquito, firefly, spider, and cicada are meant to be synonymous of summer (Dunn 2000).

Traditional knowledge about sensibility of animal species to the approach of bad or good times has been handed down by word of mouth throughout generations. It is very probable that a meteorological-sensibility allows certain animals to react to atmospheric variations and then indicate important weather phenomena. Insects serve as crucial exam- 
ples in the listening of these phenomena. For the old Chinese farmers they were the best climatic indicators of change (Jin 1997). The cricket wodey mekeri (several species of blackish crickets are labeled under this name) appears in the passage from the dry season to the rainy season, which means the fields can be prepared (Seignobos et al. 1996). Among the Bushmen of the Kalahari the annual emergence of several insects was used as an indicative of the passage of time, and many insects had their names taken from the events that coincided with the time of their appearance (Green 1998).

Ladybugs are considered as foretellers of luck in many parts of the world (Majerus 1994), while wasps are used as indicators of danger in Japan (Ramos-Elorduy 2000). In some parts of Russia and France people think of a cockroach as a protecting spirit, and its presence in the house is viewed as fortunate; if the cockroach leaves, its departure is taken as a sign of bad luck (Lauck 2002). The common name of death-watch beetle, given to Anobium tesselatum F. (Ptinidae), sufficiently expresses the popular prejudice against this insect. It is believed that the solemn death-watch beetle clicks to hour of someone's death (Cowan 1999). In Northwestern Melanesia some native groups diagnose the illness of patients by the presence or absence of lice. Slight fevers can cause an exodus of body lice that indicates oncoming illness (Posey 1987). The good luck associated with the spiders is frequently related to money matters, and the belief in a money-bringing or gift-giving spider is widespread (Lauck 2002).

The science of semiotics refers to the study of signs and symbols in various fields, especially language (Thompson 1995). Considering animals, their images and transmitted signals are frequently transformed into perceived meaningful signs and then can be investigated through a semiotic approach. The semiotic significance of animals was studied by Marques (2002) from the point of view of the ethnoecology who said the semiotic approach assumes that the cultural/informational web is formed by intermingling not only the knowledge which is generated through the direct interactions between human experience and the stimuli of the environment, but also the feelings, beliefs and behaviors that human beings express.

The present paper aims to record the semiotic meanings that are given both to the appearance and/ or behavior of insect species according to the ethnoentomological knowledge of the inhabitants of the village of Pedra Branca, Bahia State, Brazil.

\section{MATERIALS AND METHODS}

Data presented here are part of a broader research project that aims to record the ethnoentomology of Pedra Branca's villagers. A former settlement of the Kiriri Indians that was established by the Portuguese pioneer Gabriel Soares de Souza in the sixteenth century, the village of Pedra Branca is situated at the Middle Paraguaçu, west central region of Bahia State, northeastern Brazil (Paraíso 1985). (The Kiriri people do not live there anymore.) It is inside the municipality of Santa Terezinha (which is also the capital), but it is about $13 \mathrm{~km}$ away from it. This village is located at the base of the Serra da Jibóia, a mountain range of about $225 \mathrm{~km}^{2}$ of area whose peak elevation is $805 \mathrm{~m}$ above sea level. It lies between $12^{\circ} 46^{\prime}$ south latitude and $39^{\circ} 32^{\prime}$ west longitude (Juncá et al. 1999).

In 1991, the resident population in the municipal area of Santa Terezinha was 8,851 individuals (Centro de Estatística e Informação 1994). The population in the district of Pedra Branca in 1991 was nearly 400 persons (about 80 families according to the local Health Assistant), who depend on cultivation of cassava (Manihot esculenta Crantz) as their main economic activity. Livestock production is also important, mainly cattle and goats.

This region, which is totally included in the Drought Polygon, has a semi-arid climate with a mean annual temperature of $24.3^{\circ} \mathrm{C}$ and a mean annual rainfall of $582 \mathrm{~mm}$. The rainy period lasts from November to January. The vegetation of the Serra da Jibóia includes campo rupestre savannas on the peaks; dense, ombrophilous Atlantic coastal forest in the valleys and on the slopes; semi-deciduous for- 
est at the base; and arboreal Caatinga in the north. The soil is good for agricultural activities and suitable for livestock-raising (Centro de Estatística e Informação 1994).

Fieldwork was carried out over 64 days from February to May 2001. Open-ended interviews followed ethnoscientific principles by recording information on an emic approach (Sturtevant 1964). By using this kind of approach, ethnobiologists record the native's knowledge in just the way the local culture organizes, perceives, and uses its universe, not by imposing a Western understanding (Posey 1986). Nine men and twenty-five women, whose ages ranged from 19 to 82 years old, constituted the sample universe. Interviews were conducted in Portuguese since the villagers are Portuguese-speakers. Most of the interviews were recorded in microtapes; semi-literal transcriptions are deposited at the Laboratory of Ethnobiology of the Universidade Estadual de Feira de Santana (UEFS).

Data were analyzed qualitatively by considering all available information that informants have provided on the surveyed subject. Controls were performed both through consistency checking tests and reply validity tests, which make use of repeated inquiries in synchronic and diachronic conditions, respectively. One tests consistency by asking different people the same question within a very short time period. Reply validity is tested by asking the same question to the same interviewee at different times.

During the fieldwork projective tests were also conducted. These consisted in displaying both the photographs and the recent captured specimens themselves to the informants in order to prompt them to talk about the insects. Some specimens were collected and handled in accordance with the usual patterns for scientific collections, and were deposited in the entomological collection at UEFS.

\section{RESULTS AND DISCUSSION}

Twelve kinds of insects were associated with both beneficial and harmful events, as well as with the weather forecast. The types of semiotic meaning attributed to insect species, their taxonomy, the interviewees' observations, and the gender prevalence as well as the degree of consensus are shown in Table I. Apparently, people can accurately trace sounds to the actual insects producing them since the insects that call are all very common and well known species. The way local people perceive and interpret the appearance and/or behavior of certain species of insects depends on the beliefs and knowledge of each inhabitant. Thus, the same observation may have very idiosyncratic semiotic meanings in accordance with the interpretation given by the individuals themselves: fatal, funereal, auspicial, meteorological, societal, monetary, and of abundance or scarcity. The term entomoindicator is used here to refer to those insects whose behavior people think of it to indicate, predict, bring or foresee natural phenomena.

Cicadas, for example, are taken as meteorological entomoindicators because they indicate "when it is near to thunder, [when] the summer is coming" (P., 18 years old). According to the interviewees, the time of the year in which these insects show up and stay active goes from December to March. This period coincides both with the blossom of the cashew trees and with the Christmas parties. Some informants, however, state that cicada appears from September, while others say that it "squeaks all year round" (Mr. A. J., 74 years old). Indeed, cicadas appear in the hottest months of the year (in the south hemisphere) because temperature means to be a very significant environmental parameter in the regulation of the sound production and, consequently, in the reproduction (Sanborn and Maté 2000). In the "winter", on the other hand, they disappear: "It is winter now. They're all under the ground. They pull their wings out and bury themselves into the ground", Mr. A., + 40 years old.

Different cultures associate the activity of cicadas with times of winter and/or summer. To the Yukpa Indians who live in the Colombian Amazon, cicadas perform an important function in the cultivation cycle as indicators of climatic changes. The 
TABLE I

Semiotic meanings attributed to some insects by the villagers of Pedra Branca, Santa Terezinha, Bahia State, Brazil.

\begin{tabular}{|c|c|c|c|c|c|c|}
\hline \multirow[t]{2}{*}{ Type } & \multicolumn{2}{|l|}{ Insect } & \multicolumn{2}{|c|}{$\begin{array}{c}\text { Gender } \\
\text { prevalence }\end{array}$} & \multirow{2}{*}{$\begin{array}{l}\text { Degree of } \\
\text { consensus } \\
(\%)\end{array}$} & \multirow[t]{2}{*}{ Interviewee's testimony } \\
\hline & $\begin{array}{l}\text { Folk name/ } \\
\text { English name }\end{array}$ & $\begin{array}{l}\text { Tentative } \\
\text { taxonomy }\end{array}$ & Men & Women & & \\
\hline $\begin{array}{l}\text { Abundance } \\
\text { or scarcity }\end{array}$ & $\begin{array}{l}\text { Bichinho-da-fartura } \\
\text { Lacewing }\end{array}$ & $\begin{array}{c}\text { Larva of } \\
\text { Chrysopidae }\end{array}$ & 1 & 13 & 41 & $\begin{array}{l}\text { When the year is of abundance, of rain, } \\
\text { it [the larva] appears with its back full of } \\
\text { thing. And when it is not, we do not see it } \\
\text { (Mrs. V., } 54 \text { years old). }\end{array}$ \\
\hline \multirow[t]{4}{*}{ Auspicial } & $\begin{array}{c}\text { Paquinha } \\
\text { Mole cricket }\end{array}$ & Gryllotalpidae & & 1 & 3 & $\begin{array}{l}\text { It is said it's good when it appears inside a } \\
\text { house. It gives luck (Mrs. C., } 32 \text { years old). }\end{array}$ \\
\hline & $\begin{array}{l}\text { Esperança } \\
\text { Katydid }\end{array}$ & Tettigoniidae & 1 & 11 & 36 & $\begin{array}{l}\text { If a green and blue katydid appears in your } \\
\text { home you wait because you will have luck } \\
\text { (Mr. J., } 66 \text { years old). }\end{array}$ \\
\hline & $\begin{array}{l}\text { Esperança-do- } \\
\text { olho-verde } \\
\text { Green-eyed katydid }\end{array}$ & Tettigoniidae & 1 & 11 & 36 & $\begin{array}{l}\text { It is a good thing when it appears inside } \\
\text { home (Mrs. L., } 57 \text { years old). }\end{array}$ \\
\hline & $\begin{array}{l}\text { Vaga-lume } \\
\text { Firefly }\end{array}$ & Lampyridae & & 1 & 3 & $\begin{array}{l}\text { A firefly inside a house is a good happiness } \\
\text { (Mrs. L., } 57 \text { years old). }\end{array}$ \\
\hline Funereal & $\begin{array}{c}\text { Esperança } \\
\text { Katydid }\end{array}$ & Tettigoniidae & & 1 & 3 & $\begin{array}{l}\text { There is one that carries a coffin on its back } \\
\text { that notices the death (Mrs. L., } 52 \text { years old). }\end{array}$ \\
\hline \multirow[t]{2}{*}{ Fatal } & $\begin{array}{l}\text { Esperança-do-brilhoso } \\
\text { Brilliant-eye katydid }\end{array}$ & Tettigoniidae & & 1 & 3 & $\begin{array}{l}\text { That of the brilliant eye is not good } \\
\text { (Mrs. L., } 52 \text { years old). }\end{array}$ \\
\hline & $\begin{array}{l}\text { Esperança-do- } \\
\text { olho-preto } \\
\text { Black-eyed katydid }\end{array}$ & Tettigoniidae & & 2 & 6 & $\begin{array}{l}\text { That of the brilliant eye is not good } \\
\text { (Mrs. L., } 52 \text { years old). }\end{array}$ \\
\hline \multirow[t]{6}{*}{ Meteoric } & $\begin{array}{c}\text { Paquinha } \\
\text { Mole cricket }\end{array}$ & Gryllotalpidae & & 1 & 3 & $\begin{array}{l}\text { When it is near to rain it digs the soil } \\
\text { (Mrs. E., } 65 \text { years old). }\end{array}$ \\
\hline & $\begin{array}{l}\text { Cigarra } \\
\text { Cicada }\end{array}$ & Cicadidae & & 1 & 3 & $\begin{array}{l}\text { When it is near to thunder, [when] the } \\
\text { summer is coming (P., } 18 \text { years old). }\end{array}$ \\
\hline & $\begin{array}{l}\text { Formiga-cigana } \\
\text { Gipsy ant }\end{array}$ & Dorylinae & & 1 & 3 & $\begin{array}{l}\text { It is said that when it walks is [going to] } \\
\text { rain (Mrs. L., }+70 \text { years old). }\end{array}$ \\
\hline & $\begin{array}{c}\text { Grilo } \\
\text { Cricket }\end{array}$ & Gryllus sp. & 7 & 10 & 50 & $\begin{array}{l}\text { In time of rain, when it is near to rain, the } \\
\text { cricket goes up to the roof or the residences and } \\
\text { starts singing triiiiiiiiiiiii. (Mr. J., } 66 \text { years old). }\end{array}$ \\
\hline & $\begin{array}{l}\text { Vaga-lume } \\
\text { Firefly } \\
\end{array}$ & Lampyridae & & 1 & 3 & $\begin{array}{l}\text { If you see a firefly inside the house you are } \\
\text { sure of rain (Mrs. E., } 52 \text { years old). }\end{array}$ \\
\hline & $\begin{array}{l}\text { Quebra-pote } \\
\text { Jug-breaker }\end{array}$ & Hymenoptera & & 1 & 3 & $\begin{array}{l}\text { A little but that people calls it as a jug-breaker. } \\
\text { It is like a wasp. When it arrives into the houses it } \\
\text { likes a lot to call the rain (Mrs. L., }+70 \text { years old). }\end{array}$ \\
\hline \multirow[t]{2}{*}{ Societal } & $\begin{array}{l}\text { Soldadinho } \\
\text { Little soldier }\end{array}$ & Acrididae & & 1 & 3 & $\begin{array}{l}\text { When there is a lot, then people say: "There is } \\
\text { to be a fight over there" (Mrs. L., }+40 \text { years old). }\end{array}$ \\
\hline & $\begin{array}{c}\text { Esperança } \\
\text { Katydid }\end{array}$ & Tettigoniidae & 1 & & 3 & $\begin{array}{l}\text { When you are waiting for something and a } \\
\text { katydid appears you then say: "Today there was } \\
\text { a visit here and it is a good thing to me" } \\
\text { (Mr. M., } 68 \text { years old). }\end{array}$ \\
\hline \multirow[t]{3}{*}{ Monetary } & $\begin{array}{c}\text { Esperança } \\
\text { Katydid }\end{array}$ & Tettigoniidae & & 2 & 6 & It calls money too (Mrs. M., 55 years old). \\
\hline & $\begin{array}{c}\text { Grilo } \\
\text { Cricket }\end{array}$ & Gryllus sp. & 1 & 4 & 15 & $\begin{array}{l}\text { Cricket singing is calling money (Mrs. M., } \\
55 \text { years old). }\end{array}$ \\
\hline & $\begin{array}{l}\text { Vaga-lume } \\
\text { Firefly }\end{array}$ & Lampyridae & & 3 & 9 & $\begin{array}{l}\text { It is calling money when it is in a house } \\
\text { (Mrs. E., } 65 \text { years old). }\end{array}$ \\
\hline
\end{tabular}


sowing of corn begins when the "tipaína" starts to sing. When this "ballad" finishes the Yukpa know that the rainy season has arrived (Ruddle 1973). In Zambia the emergence of adult cicadas is considered as an indicative of coming rains. Then the farmers begin to prepare the fields to be cultivated. The level of intensity of their singing predicts the quantity of rain that will fall. The louder the sound, more rain expected (Mbata 1999). To the members of the Hñähñu tribe who inhabit the Mexican state of Hidalgo, Proarna sp. indicates when the day begins to become warm because it initiates its calling at ten o'clock (Maya 2000). On the other hand, cicadas are a bad omen for the Kalam people from New Guinea when they sing at a wrong time of the day or very close to the houses (Bulmer 1968).

Crickets' singing can be interpreted as a sign of rain ("There is one that, when it is near to rain, it sings. We are about to get deaf. It is a bother noise. It sings near to the rain", Mrs. M., 60 years old) or of monetary gain ("Cricket singing is calling money”, Mrs. M., 55 years old). Crickets predicting the approach of rains sing inside the houses and on the roof: "There is a time that at 7:00 pm they sing until later in the night. The black cricket sings inside the house for calling rain" (Mr. A., 73 years old). Apparently, these interpretations do not have any special meaning to local cultural practices, like planting.

Omens about crickets are common in other parts of Brazil, but they have different meanings. In the city of Caraguatatuba, São Paulo State, a black cricket in a room is a sign of sickness; a gray one a sign of money; and a green one a sign of hope (Lenko and Papavero 1996). In the state of Alagoas, northeast Brazil, a cricket announces death. That's why it is killed as soon as it sings inside the house (Araújo 1977). In the village of Capueiruçu, Bahia State, the omens with crickets occur in agreement with the constancy of their singing: pregnancy is foretold if the insect performs a non-stop singing. If it sings and stops, then some money is expected (K.L.G. Lima, unpublished data). In the history of Brazil this insect was the announcer of a good event for the crew of the captain Álvares Nuñes Cabeza de Vaca. The reserve of drinking water was gone when a cricket, which had been silent until that moment of the travel, started to sing foreseeing the proximity of lands (Lenko and Papavero 1996).

According to Kritsky and Cherry (2000), the cricket occurs in different roles in folklore and superstition. As a prognosticator, they state, "the cricket forecasts rain, death, or the approach of an absent lover." The Chinese used to shut a cricket inside a little cage in order to have good omens (Carrera 1991). In Barbados, the presence of a noisy cricket in the house indicates that money is coming to the house, so nobody must kill or evict the insect; another type of cricket, which is not as noisy as the first, is associated to illness or death in the family when it comes into the house (Forde 1988).

Scientifically, only male crickets can "sing". At the base of each forewing the male has a thick vein with a protruding row of teeth. Like a file, the vein is etched with from 50 to 300 ridges. On the upper side of the wing is a thick hardened area that serves as a scraper. A "singing" cricket simply raises his forewings to a $45^{\circ}$ angle over his back, and rubs the file of one wing against the scraper of the other, to produce the chirp (Berenbaum 1995). It is known that the snowy tree cricket of the United States is sensitive to heat, and chirps faster as the temperature rises; if one adds 39 to the number of chirps in 15 seconds, it is possible to determine the temperature in degrees Fahrenheit (Dolbear 1897).

The presence of a mole cricket, locally known as "paquinha”, “jeguinho”, "cachorrinho-d'água”, and "cava-chão" (genera Scapteriscus and Neocurtilla, Gryllotalpidae), has a double meaning since it brings both luck ("It is said that it is good when it appears inside the house. It gives luck", Mrs. C., 32 years old) and rain. The mole cricket digs tunnels under the soil. So, people almost always interpret this behavior as a meteorological sign because "when it is near to rain it digs the ground, it softens the land. It foresees the rain" (Mrs. E., 65 years old). Maybe there really is a connection between the act of the insect digging new galleries and rainfall. It is 
said that Gryllotalpidae "just appear on the surface of the ground after heavy rains or during their flights of dispersion to colonize new areas" (Fowler 1994). In Zambia, Gryllotalpa africanus Pal brings luck to everyone who sees it (Mbata 1999).

The gypsy ant (Iridomyrmex sp.?) is another insect that indicates rain by its presence: "When it gets out [appears] it is rain" (Mrs. L., + 60 years old). In the city of Soledade, Paraíba State, two insects are indicators of rain (Lucena et al. 2002). The stingless bee called arapuá, Trigona spinipes (Fabr. 1793), indicates the closeness of rain "when it makes the mouth [the entrance of the nest] turned up toward. If it makes it turned down toward it is not going to rain". The ant indicates the rain "when it makes a tall nest" or "when it closes the nest's mouth [opening]. Rossato (1984) recorded several folk interpretations about weather forecasts linked to the leaf-cutting ants (Atta spp.) in the state of São Paulo. For example, if someone breaks an ant's nest on a rainy day it is believed the sun will reappear; ants opening "olheiros" [nest entrances] in humid localities indicate that the year will have less rain; ants trying to open "olheiros" in an arid area indicate a year with much rain; agitated ants are a sign for abundant rains in the next few hours; a lot of new dirt around the "olheiros" indicates the proximity of rain. Literature says that these ants prefer to do the cutting of leaves at night in order to avoid predators, but when they sense the arrival of rains in the evening, by unknown mechanisms, they work during the day (Oliveira 1990). A recent Stanford study concluded that the movements of ants are undoubtedly tied to weather conditions (Lauck 2002).

Pedra Branca's villagers interpret the appearance of fireflies (Coleoptera, Lampyridae) in the houses both as a sign of rain and money arrival: "If you see a firefly inside the house you can be sure of rain" (Mrs. E., 52 years old); "People say that firefly inside a house attracts money" (Mrs. L., 57 years old). In the countryside of India a bunch of fireflies seen at night on the trees in the forest indicates that the monsoon will arrive soon (Rahudkar 1998).

Some villagers believe that the "bichinho-da- fartura" (abundance bug, as it would be called in English) has the power to indicate abundance or scarcity of food. Specimens of the "bichinho-dafartura" were not collected, but they are probably the larvae of lacewings of the family Chrysopidae (order Neuroptera). It is known that the larvae of Leucochrysa and Ceraeochrysa show hooked bristles on their backs to which they fix minute bits and pieces of debris to give them a kind of camouflage. For that reason, they are called as trash-carrying bugs too (Hogue 1993).

"People here in the county know when the year is going to be good, when it is going to be bad, when it is going to have abundance. People say: 'I've found the bichinho-da-fartura.' It carries on its back that little bundle of that height like this [showing the height of the bundle]. [The things] that is going to give in the next year. But it takes the flesh (cast skins) all on its back. It's even funny. The bichinho-da-fartura, there is a time that it is all white. Then people say: 'Uau! Next year we will have a lot of manioc, a lot of manioc flour, because the bichinho is loaded.' And then it is a really flesh (cast skins). Then, there is a time people find it bare-naked" (Mrs. E., 52 years old).

"When the year is bad it comes naked. I've already seen it bare, naked. When the year is [of] good time, having a lot of thing, it comes with so many things, that even little bits of a thing looking like sticks it has on its back. A little beautiful thing, that bug. It is tiny, but it has so many things on its back that we just see the little beak of that size" (Mrs. L., + 60 years old).

Hogue (1993) points out that the larval habitats vary considerably and include vegetation, sandy soil, bark crevices, and cavities under objects on the ground. By observing the presence (or absence) and the type of material fixed to the bristles people interpret it as times of abundance or scarcity of resources. In some occasions, the "bichinho-da-fartura" was named as "aranha-da-fartura" (abundance spider). According to the given morphological description it is possible that some informants have confused it with a velvet ant: "Its back is all striped with white 
and black" (Mrs. A., 63 years old). In the north of the state of Minas Gerais, "fartura" refers to Pseudococcus setosus (Hempel 1900) (Homoptera, Pseudococcidae); its name comes from the great quantity of waxy secretion, similar to flakes of cotton, which covers its body (Buzzi 1994).

A group of nymphs of grasshoppers, known as "soldadinhos" (little soldiers), when concentrated near to a residence, indicates the occurrence of a fight between the inhabitants of that house: "When there is a lot of them people say: 'There is going to be a fight over there"" (Mrs. L., + 40 years old). This is an example of a societal entomoindicator. In the Andean region, when the dragonfly Aeshna cornuta (Förster 1999) flies near to or inside a residence, it is said that the family will receive a letter (Venero 1987).

Depending on the ethnospecies of katydid (Orthoptera, Tettigoniidae) people see, they are supposed to be considered as good or bad omens. For example, the green-eyed katydid is a good sign, while the black-eyed katydid and the brilliant-eyed katydid are bad signs. There is also an ethnospecies that "has a coffin on its back that harbingers the death" (Mrs. L., 52 years old). Katydids of green color are, sometimes, perceived and identified as praying mantises. Their appearance is interpreted as a good thing. Local names in Portuguese and Spanish given to katydids mean "hope", in reference to the green color of so many species in the family, the symbolic color of this emotion (Hogue 1993). Other cultures see these insects in a similar way. The inhabitants of the village of Marituba do Peixe, in the state of Alagoas, interpret the appearance of the white-mouth katydid inside a house as an indication of a coming visitor; on the other hand, the black-mouth katydid is a signal of a bad omen (Costa Neto 2000a). In the village of Capueiruçu, Bahia State, the appearance of katydids is considered as an auspicious entomoindicator since these insects bring good luck: "I am frightened when a katydid rests on me, but I do not remove it from me. Otherwise my luck goes away" (K.L.G. Lima, unpublished data).
Different cultures see the appearance of other insect species with funereal signs. The Aymara people from Bolivia took the presence of a certain rare moth as an omen of death. And the ancient Mexicans feared one of the large night-flying moths as a messenger of death (Clausen 1954). And the death'shead sphinx moth, a large moth that sometimes makes a strident sound when it flies and has a skullshaped marking above its thorax, represented Satan and was thus an emblem of death (Lauck 2002). On the other hand, the Japanese treat any butterfly that comes into their houses friendly because they believe souls usually take butterfly shape in order to announce that they are leaving the body for good (Lauck 2002).

The beliefs in the augural power of insects in the village of Pedra Branca are deep-rooted in the local tradition and are transmitted from generation to generation through oral culture: "The cricket, when it is singing, the older ones said that money is going to arrive (Mrs. L., 57 years old). Some of the observations appear to be widely shared among individuals. This is the case for the augural sign ascribed to crickets' calling songs as indicative of coming rains; it presents a $50 \%$ of consensus. Another example is the augural sign ascribed to the larvae of lacewings as harbingers of abundance or scarcity: $41 \%$ of consensus. Others are more idiosyncratic. This is the case of the mole crickets whose appearance inside a house is meant to be auspicial; just $3 \%$ of the interviewees have mentioned it.

Apparently, those insects that harbinger pleasant events are not driven away or killed by those individuals who believe in their augural capacity, such as the green-eyed katydid ("People say that the green one is a good thing. Nobody kills it", Mrs. R, + 30 years old) and the "bichinho-da-fartura" (We do not like to kill it because it is said it is not good to kill, Mrs. M., 73 years old).

Symbolic considerations apart from superstitions, the reading of certain entomoindications finds scientific support for the current condition, if not for prediction. For example, the absence of cer- 
tain species of insects can be taken as a sign of environmental pollution, while the presence of other species can indicate unhealthy conditions (Posey 1987). Species that have a larval aquatic period, such as the dragonflies, are indicators of anthropogenic environmental disturbance, just as the presence of horseflies (Tabanidae) near the margins of river banks indicates the presence of game for the Brazilian indigenous hunters (Lenko and Papavero 1996). Besides, insect-based artifacts and their own remains are used as chronologic and topographical indicators in archeological works: numerous insects are depicted in prehistoric petroglyphs and pictographs in Europe, South Africa, and North America (Hogue 1987).

Insects, like all other living organisms, are subjected to changes in the abiotic and biotic components of their environments. As Albuquerque (2004) points out, these changes include both predictable and unpredictable events. The former are long term changes associated to the seasons of the year, but also include short and long term changes that vary in their predictability levels, such as the diary cycles of daylight, temperature, and humidity. The latter are characterized by prolonged droughts and brusque increases and/or decreases of temperature associated to the approach of a cold or warm front. The understanding of how insects deal with the length of environmental changes, both predictable and unpredictable, is essential to comprehend how these animals have supplanted the adversities of their environs.

The ethnoentomological knowledge of insect species and their interactions to human beings is meant to be of relevant importance as a significant source of information on the species, their life cycles, and behavior. By studying the folk entomological knowledge of a given human culture would not only assist researchers in their understanding on the social-cultural-ecological roles played by insects, but also would help them to comprehend how native cultures interact deeper with their environments and use their resources appropriately (Blake and Wagner 1987). Thus, it is hoped that the data now available will be incorporated into a curriculum by those researchers interested in insect conservation and ethnobiology as well. Additionally, decision-makers would be able to apply proper conservation programs and management practices only if they recognized that the cultural perspectives is to be taken into account in every debate focused on biological conservation policy (Costa Neto 2000b).

Some insect auguries, such as abundance or scarcity, auspicial, funereal, fatal, societal, and monetary can be explained by metaphor. For example, when one sees the abundance of object carried on larva of Chrysopidae he associates it with abundance of food; or when one interprets the color of katydids as a bad or good omen. On the other hand, the meteoric auguries should be reasoned by the synchronicity and the ecological triggering (cicada - summer; Atta ants - rains), since they will be based on accurate ecological observation and may have direct practical consequences.

\section{ACKNOWLEDGMENTS}

I am very grateful to Dr. Luis O'Brien and Miguel Alexiades, as well as to two anonymous referees, for their useful criticisms and suggestions on the manuscript.

\section{RESUMO}

Este artigo discute os significados semióticos atribuídos ao aparecimento e/ou comportamento dos insetos de acordo com o conhecimento etnoentomológico dos moradores do povoado de Pedra Branca, Bahia, Brasil. Dados foram obtidos entre fevereiro a maio de 2001 através de entrevistas semi-estruturadas e gravadas com 9 homens e 25 mulheres, cujas idades variaram de 19 a 82 anos. Os dados foram analisados pelo método do modelo de união, que considera toda informação disponível sobre o assunto pesquisado. Vinte tipos de insetos foram associados com acontecimentos bons e ruins, assim como a indicação de mudanças atmosféricas. O modo como os indivíduos percebem e interpretam o aparecimento e/ou comportamento de certas espécies de insetos depende da formação cultural de cada indivíduo. Foram registrados os seguintes 
significados semióticos: funesto, funéreo, ditoso, meteórico, societário, monetário e de abundância ou escassez. As crenças no poder augural dos insetos em Pedra Branca estão bem arraigadas na tradição local, sendo transmitidas de geração a geração pela via oral. Espera-se que as informações sejam levadas em consideração por pesquisadores interessados em estudos de conservação da entomofauna local e de etnobiologia.

Palavras-chave: bioindicador, etnoentomologia, conhecimento tradicional, significado semiótico.

\section{REFERENCES}

Albuquerque GS. 2004. Adaptações dos insetos a diferentes níveis de previsibilidade das mudanças ambientais: uma visão geral. In: CONGRESSO BRASileiro DE ENTOMOlogia, 20, Gramado, RS, Brasil, SEB, 147 p.

Araújo AM. 1977. Medicina rústica. São Paulo: Companhia Editora Nacional, 301 p.

BERENBAUM MR. 1995. Bugs in the system: insects and their impact on human affairs. Cambridge: Perseus Books, 377 p.

Blake EA And Wagner MR. 1987. Collection and consumption of Pandora moth, Coloradia pandora lindseyi (Lepidoptera: Saturniidae), larvae by Owens Valley and Mono Lake Paiutes. Bull Ent Soc Am 33: 23-27.

BULMER RNH. 1968. Worms that croak and other mysteries of Karam natural history. Mankind 6: 621639.

BuzZI ZJ. 1994. Coletânea de nomes populares de insetos do Brasil. Curitiba, PR, Brasil, 230 p.

Carrera M. 1991. Insetos, lendas e história. Brasília, DF, Brasil, Thesaurus, 137 p.

Centro de Estatística E InformaÇão. 1994. Informações básicas dos municípios baianos: Recôncavo Sul. Governo do Estado da Bahia, Salvador, BA, Brasil, p. 543-563.

Clausen LW. 1954. Insect fact and folklore. New York: Macmillan Company, $194 \mathrm{p}$.

Clausse R. 1973. Meteorologia e folclore. O Correio da Unesco 10: 58-62, 64.

Costa Neto EM. 2000a. Introdução à etnoentomologia: considerações metodológicas e estudo de casos. UEFS, Feira de Santana, BA, Brasil, 131 p.
Costa Neto EM. 2000b. Sustainable development and traditional knowledge: a case study in a Brazilian artisanal fisherman's community. Sust Dev 8: 89-95.

Cowan F. 1999. Death-watch beetles and the flypaper sellers of London. In: HoYT E AND SCHULTz T (Eds), Insect lives: stories of mystery and romance from a hidden world. J Wiley \& Sons, New York, USA, p. 53-61.

DOLBEAR AE. 1897. The cricket as a thermometer. Am Natur 31: 970-971.

DUNN RR. 2000. Poetic entomology: insects in Japanese haiku. Am Ent 46: 70-72.

FORDE GA. 1988. Folk beliefs of Barbados. Barbados: National Cultural Foundation, 47 p.

Fowler H. 1994. Canibalismo entre insetos. Ciência Hoje 18: 15-16.

GREEN SV. 1998. The bushman as an entomologist. Antenna 22: 4-8.

Hogue CL. 1987. Cultural entomology. Ann Rev Ent 32: 181-199.

Hogue CL. 1993. Latin American and entomology. University of California Press, Berkeley, USA, 536 p.

JIN XB. 1997. Chinese cricket culture: an introduction to cultural entomology in China. Available at: http://www.insects.org/ced3/chinese_crcul.html.

Juncá FA, Freitas MA, Alves L, Guerreiro W AND PASCHOAL E. 1999. Herpetofauna da Serra da Jibóia - Bahia: novas ocorrências. In: ENCONTRO DE Zoologia do Nordeste, 12, Feira de Santana, UEFS, Feira de Santana, BA, Brasil, 412 p.

KRITSKY G AND CHERRY R. 2000. Insect mythology. Lincoln: Writers Club Press, 140 p.

LAUCK JE. 2002. The voice of the infinite in the small: re-visioning the insect-human connection. Boston: Shambhala Publications, 309 p.

LENKO K AND PAPAVERO N. 1996. Insetos no folclore. São Paulo: Plêiade/FAPESP, 468 p.

LuCENA RFP, Souza EP, ARAúJo HFP AND MouRÃO JS. 2002. O canto das chuvas: animais da caatinga utilizados como bioindicadores de chuva, uma abordagem etnozoológica nas comunidades rurais de Soledade - PB. In: Simpósio BRASILEIRO de Etnobiologia e Etnoecologia, 4, Recife, PE, Brasil, 156 p. 
Majerus MEN. 1994. Ladybirds. Harper Collins Publishers, London UK, 345 p.

Marques JGW. 2002. O sinal das aves. Uma tipologia sugestiva para uma etnoecologia com bases semióticas. In: Albuquerque UP, Alves ACG, Lins E Silva ACB And Silva VA (Org), Atualidades em etnobiologia e etnoecologia. SIMPÓsIo BRASILEIRo de Etnobiologia E Etnoecologia, Recife, PE, Brasil, p. 87-96.

MAYA EMA. 2000. Estudio etnoentomológico de la comunidad Hñähñu, El Dexti - San Juanico, Ixmiquilpan, Hidalgo. UNAM, Iztacala, 125 p.

MBATA KJ. 1999. Traditional uses of arthropods in Zambia: II. Medicinal and miscellaneous uses. The Food Insects Newsl 12: 1-7.

Oliveira MTC. 1990. A dura vida das formigas. Superinteressante, p. 44-49.

PARAÍso MHB. 1985. Os Kiriri Sapuyá de Pedra Branca. Centro de Estudos Baianos da UFBA. Salvador, BA, Brasil, 96 p.

Posey DA. 1986. Etnobiologia: teoria e prática. In: RIBEIRo D (Ed), Suma etnológica brasileira: etnobiologia Petrópolis: Vozes/Finep, p. 15-25.

Posey DA. 1987. Temas e inquirições em etnoentomologia: algumas sugestões quanto à geração de hipóteses. Bol Mus Para Emilio Göeldi 3: 99-134.

PRENDERGast HDV, DAVIS SD AND WAY M. 1999. Dryland plants and their uses. In: POSEY DA (Ed), Cultural and spiritual values of biodiversity London: Intermediate Technology Publications, p. 233-235.
RAHUDKAR WB. 1998. Stemming knowledge erosion: rediscovering the past. Honey Bee 9: 10-11.

RAMOS-ElORDUY J. 2000. La etnoentomología actual en México en la alimentación humana, en la medicina tradicional y en la reciclaje y alimentación animal. In: Congreso Nacional de Entomología, 35, Soc Mex Ent, Acapulco, p. 3-46.

Rossato JC. 1984. A saúva no folclore paulista. Anuário do Folclore 14: 1-8.

RUDDLE K. 1973. The human use of insects: examples from the Yukpa. Biotropica 5: 94-101.

SANBORN AF AND MATÉ S. 2000. Thermoregulation and the effect of body temperature on call temporal parameters in the cicada Diceroprocta olympusa (Homoptera: Cicadidae). Comp Bioch \& Phys 125: 141-148.

Seignobos C, Deguine JP And Aberlen HP. 1996. Les Mofu et leurs insectes. JABA 33: 125-187.

Sturtevant WC. 1964. Studies in ethnoscience. Am Anthrop 66: 99-131.

THOMPSON D. 1995. The concise Oxford dictionary of current English. Oxford University Press, Oxford, UK, 1454 p.

VEnero JL. 1987. La fauna e el hombre andino. Inf Doc de Trab 8. (Cuzco: Projeto FAO/Holanda), 45 p. 